\title{
Ethical and Legal Aspects of Using Genome Editing Technologies in Medicine (Review)
}

\author{
DOI: 10.17691/stm2019.11.3.16
}

Received June 14, 2019

M.N. Karagyaur, PhD, Senior Researcher, Institute of Regenerative Medicine, Medical Scientific and Educational Center ${ }^{1}$; Senior Researcher, Faculty of Medicine';

A.Yu. Efimenko, MD, PhD, Head of the Laboratory of Tissue Regeneration and Repair, Institute of Regenerative Medicine, Medical Scientific and Educational Center ${ }^{1}$; Associate Professor, Faculty of Medicine ${ }^{1}$;

P.I. Makarevich, MD, PhD, Head of the Laboratory of Gene Cell Therapy, Institute of Regenerative Medicine, Medical Scientific and Educational Center ${ }^{1}$; Associate Professor, Faculty of Medicine ${ }^{1}$;

P.A. Vasiluev, Junior Researcher²; Medical Resident ${ }^{3}$;

Zh.A. Akopyan, MD, PhD, Deputy Director for Academic and Scientific Affairs, Medical Scientific and Educational Center ${ }^{1}$; Vice-Dean of the Faculty of Medicine ${ }^{1}$;

E.V. Bryzgalina, PhD, Head of the Department of Education Philosophy';

V.A. Tkachuk, DSc, Professor, Academician of the Russian Academy of Sciences,

Director of the Institute of Regenerative Medicine, Medical Scientific and Educational Center ${ }^{1}$;

Dean of the Faculty of Medicine ${ }^{1}$; Head of Laboratory ${ }^{4}$

${ }^{1}$ Lomonosov Moscow State University, Bldg 10, 27 Lomonosov Avenue, Moscow, 119991, Russia;

${ }^{2}$ Institute of Gene Biology, Russian Academy of Sciences, 34/5 Vavilova St., Moscow, 119334, Russia;

${ }^{3}$ Bochkov Research Centre for Medical Genetics, 1 Moskvorechye St., Moscow, 115522, Russia;

${ }^{4}$ National Medical Research Center of Cardiology of the Ministry of Health of the Russian Federation,

15A $3^{\text {rd }}$ Cherepkovskaya St., Moscow, 121552, Russia

According to many experts, the turning point in the development of genome editing technologies (GET) was 2012, when Feng Zhang and Jennifer Doudna independently proposed the adaptive bacterial immunity system CRISPR/Cas9 for editing the genome of living cells of eukaryotic organisms. Since then, the range of applications of CRISPR/Cas9 technology and related GET has continued to grow like an avalanche. Thus, new genetically modified microorganisms, plants, and animals have been created, the experimental studies on the genetic foundations of life have greatly expanded, and revolutionary approaches to therapy and prevention of incurable diseases have been developed.

However, the indisputable advantages of GET are associated with high risks (real and potential) to the environment, human health, and society as a whole. Significant progress in the genome editing in eukaryotes has led to a rapid appearance of humans with an "improved" genome, despite the openly expressed opposition of leading scientists working in this field. Among them, David Baltimore, Paul Berg, Jennifer Doudna, George Church, and Martin Jinek are calling for a global suspension of work with human embryos until the technical, legal and ethical standards in this area are developed.

There is an urgent need for the development of an unambiguous public position and improvement of the regulatory framework for the GET, including that in the Russian Federation; the present review attempts to address the urgent issue of GET-related regulations.

We discuss various approaches to regulating the use of GET in medicine. We review legal acts and ethical recommendations around the world concerning the GET-mediated modification of the plant and animal genetic material for the purpose of creating medical products and drugs. We also address the sensitive issue of editing the genome of human cells (somatic or germ). Special attention is paid to the relevant legal and ethical standards exiting in the Russian Federation.

The presented data allow for a better understanding of the current situation and the areas of further research into GET, where the development and implementation of regulatory standards are especially urgent.

Key words: genome editing technologies; embryo genome modification; CRISPR/Cas9; legal regulation of GMO; ethical standards in medicine.

Corresponding author: Maxim N. Karagyaur, e-mail: m.karagyaur@mail.ru 


\section{Introduction}

Genome editing technologies (GET) - ZFNs, TALENs, and CRISPR/Cas9, etc. - are powerful tools for making precise changes in genomic DNA. The universality of the genetic code allows you to modify any biological species: from bacteria and viruses to higher plants, animals, and humans. The GET open up great opportunities for creating new strains of producing microorganisms, varieties of plants and breeds of animals that are resistant to diseases and adverse factors $[1,2]$. These novel techniques make it possible to find solutions to urgent medical problems, such as elucidating the molecular mechanisms of diseases, diagnosing and treating incurable diseases (HIV, oncological and orphan diseases), as well as controlling the spread of vector-borne infections (malaria, sleeping sickness, fever, etc.) [3, 4].

However, such unprecedented abilities of GET and international regulations of their use were compromised by the episode of human zygote genome editing and subsequent birth of babies with a modified genome in 2018 in China [5]. The concerns about undesirable and adverse impact of GET on the environment, society and human health will inevitably lead to tightening the control mechanisms and regulations within the academic community and the national legislation. This task is rather challenging because achieving any international consensus on the legal and ethical issues is complicated by the great variability of sociocultural conditions and the level of biological research in different countries. Despite the urgency of the problem, some countries have yet to develop their position on the legal regulation of GET.

The growing popularity of GET and the need to understand the ethical and legal aspects of their use prompted us to summarize the available information on the bioethical and regulatory aspects of GET in medicine in the Russian Federation and around the world. The present review may not be fully comprehensive and thorough, since the GET and the related legal acts continue to be modified and updated.

\section{Rationale and basic approaches to ethical and legal regulation \\ of genome editing technologies}

In 2015, a graduate of the University of Chicago, Josiah Zayner, launched the production of commercial kits that allow one to edit the genomes of bacteria, yeast and other cells using the CRISPR/Cas9 system at home [6]. As a fact, these kits did not represent any threat and were aimed at popularizing the latest achievements of genetic engineering. Yet, they clearly demonstrated the ease, with which GET could be used outside of laboratories, including potential biological weapons. The wariness of the society has grown into a sense of direct threat emanating from the GET after twin girls with the edited genome were born in China in 2018 [5]. The rapid development of GET and the example of their abuse for inheritable editing of the human genome, called for immediate development of strict, unambiguous and thoughtful national and international legal standards, which would not impede the scientific research into GET, or their fair and justified application in medicine.

One of the first steps towards the regulation of genetic engineering technologies were taken in the 1975 conference in Asilomar (USA). During this meeting, the safety criteria and safety providing tools for genome changing experimentation with living organisms were proposed [7]. These principles and criteria can serve the basis for developing the updated recommendations on the safe use of GET [7-9]. At the same time, in order to keep them relevant and ensure the fair and responsible use of GET, these regulatory principles need to be reviewed and updated in a timely manner.

A tremendous interest in the GET, coupled with a lack of a clear understanding of their legal dimensions, prompted the world community to hold international summits on human genome editing $\left(1^{\text {st }}\right.$ and $2^{\text {nd }}$ International Summit on Human Genome Editing, 2015 and 2018) $[10,11]$. Those meetings were aimed at developing international legal and ethical standards regulating the GET, as well as creating institutions to monitor and enforce these regulations. At the same time, there are major obstacles to achieving the global consensus on this contentious issue. Among them, there are national differences in assessing potentially hazardous products and technologies, very different technical capabilities and contrasting points of view on key ethical issues.

According to the existing system of legal regulation, each country decides for itself how to control new technologies or products, i.e., consider them dangerous or safe until proven otherwise [12]. On the one hand, the hasty translation of promising, but insufficiently studied technology to the clinic can sometimes lead to a tragedy. Thus, in 1999 at the University of Pennsylvania, during a clinical trial of the adenoviral delivery of the ornithine transcarbamylase gene, one of the subjects, Jesse Gelsinger, died as a result of an adverse immune response $[8,13]$. There are well known cases of leukemia that developed during clinical trials when transplanted hematopoietic stem cells modified with genome integrating retroviruses (IL-2RY gene delivery) were used for the treatment of $X$-linked severe combined immunodeficiency (SCID-X1) [9, 14]. These cases impeded the introduction of viral vectors for gene therapy into the clinical practice.

On the other hand, overestimating the existing risks and overtightening the legal restrictions may inhibit the progress of scientific knowledge [15] and limit the development of fundamental and translational research. For example, in the early 2000s, discussions about human embryonic stem cells in the US resulted in closing a number of projects on human embryonic material, which negatively affected the developments in this field 
of science [16]. Currently, many countries maintain limitations on the editing of germ cells, zygotes, and embryos because (as the explain) of the lack of sufficient knowledge of long-term effects of GET. However, a complete ban on scientific research in this area will narrow the options for developing innovative treatments for hereditary diseases $[15,17]$. Moreover, long delays in the registration of new bio-products or a ban on the development of new technologies compels the doctors to repeatedly use older and less safe medications and, on top of that, reduces the interest of investors in financing the cutting edge research projects in this area [18].

The optimal solution is to maintain a balance between these two approaches, since each of them, if inadequately applied, can delay the development of GET and science in general. One possible example of the adequate legal regulation is the so-called conditional approval, which is a compromise between the free progress of science and public/government control over it. This approach is based on determining the degree of risk (high/medium/low) of a new technology or drug; at a low or medium risk, these technologies are authorized for clinical use for a limited time even before obtaining full results on efficacy/safety (USA, Japan, South Korea, Singapore). In this approach, there is a mechanism for automatically revoking the "approval", if clinical studies did not confirm the efficacy or if the risks of using a technology or a drug were still significant.

This model of "conditional approval" was previously proposed in some jurisdictions for gene-therapeutic, cellular and tissue-engineered projects [19, 20]. The criteria for assessing the risk included: autologous or allogeneic nature of the cells in question, the degree of their modification, and the way of using them (alone or in combination with other drugs) [8]. Presumably, a similar approach can be used to commercialize products resulted from GET. The potential of such products is currently studied in clinical trials: from treating HIV infection and blood diseases by modifying hematopoietic stem cells $[3,21]$ to treating B-cell lymphomas with CART-lymphocytes [22] and treating bullous epidermolysis by genetically modified epithelial cells [23].

Significant differences exist in different judicial systems regarding the control over new areas of science and technology [8]. Therefore, it is often difficult to determine which type of regulation is more effective. If the technology is regulated, there is a good chance to overestimate or underestimate its potential threat or leave alternative methods of its application without proper control. In turn, regulating the turnover and use of the end products requires many more resources, and can create a negative information background based on the suspicions that the government is ignoring potentially dangerous technology.

To date, there is no sufficient experience in controlling the safety of organisms modified with the help of GET; however, data on transgenic organisms (genetically modified objects - GMO - obtained using recombinant
DNA technologies) demonstrate the disadvantages of technology-oriented regulation as compared with the careful control over safety and quality of the final product. The overwhelming majority of GMO has been shown to be safe and meet the expected quality criteria $[18,24]$; however, some GMO demonstrated surprising effects that were difficult to foresee. For example, the increased productivity of genetically modified bacteria producing L-tryptophan (Showa Denko K.K., Japan) led to non-enzymatic intracellular dimerization of tryptophan and its precursors with the formation of a highly toxic product. The limited marketing (for only 3 months) of a biologically active supplement containing such L-tryptophan without proper safety assessment resulted in 37 deaths and more than 1500 cases of disability [25].

However, the safety of GMO is determined not by the technology used, but by the specific genetic modification (mutagenesis, trans- or cis-genesis, GET). Shutting down or activating certain genes, even without transgenesis (insertion of DNA from evolutionarily distant organisms), can cause an imbalance of signal and metabolic cascades, change the body's ability to absorb/ accumulate nutrients and excrete metabolic products and toxins, or change the pathogenicity, resistance, invasiveness, etc. [26]. In this respect, the assertion that the accidental (mutagenesis) or directed (genome editing) intervention in the genome is safer than transgenesis, sounds doubtful $[13,27]$. There are certain analogies between the DNA changes obtained through mutagenesis or genome editing and changes observed in nature [27-29]; however, not all natural mutations are favorable.

The choice between regulating the technology and regulating the final product differs in different countries (Figure 1). Importantly, the use of GET (from plant modification to changes in the human genome) is largely determined by this choice. The United States shows a good example of successfully using the product-oriented approach. There, every new product is considered potentially dangerous; all products are tested using the same standard procedures, and regulated according to their mechanism of action [8]. Supervising the final product allows the authorities to control its proper use in the clinic [8].

In addition to the mentioned approaches, alternative systems of legal regulation are currently under development; those are intended to establish more efficient and flexible control on research into modified organisms and products derived from them [30-32]. All of these legal alternatives are, in essence, similar to the "conditional approval" and are based on the risk assessment considering the degree of genome modification (from insignificant to transgenesis) and the resulting toxicity, invasiveness or resistance of the final GMO [29].

Both the state (through legislative activity) and the professional community (through recommendations and directives) can guide and control the regulatory 


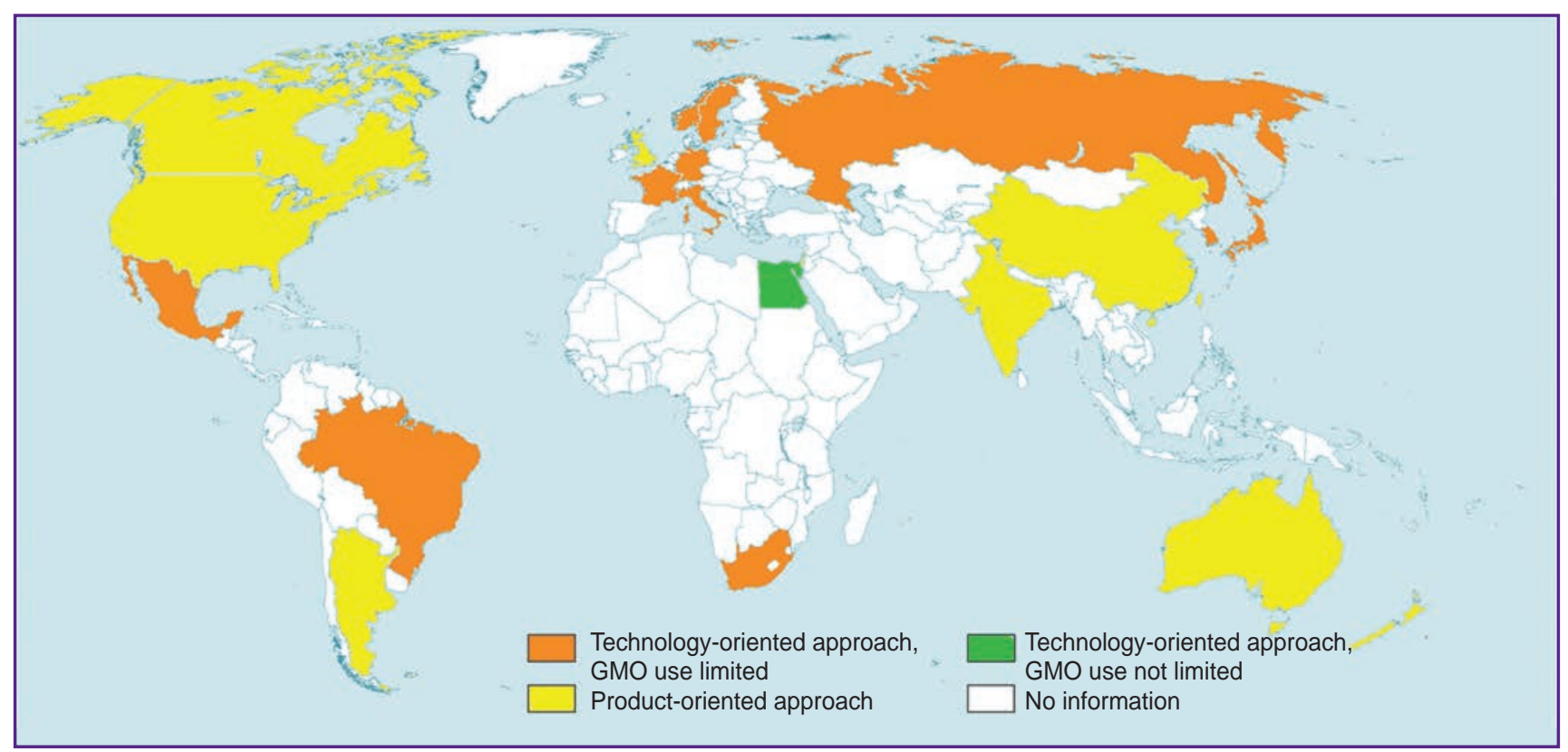

Figure 1. The product- and technology-oriented approaches to the regulation of GMO and GET in countries of the world

standards [8]. The involvement of a professional community in the national legislation can make the regulation more flexible and responsive to changes while maintaining the pace of research [8].

In addition to the legal regulation of GET, its application is largely determined by the totality of ethical standards adopted at the international level (Declaration of Human Rights, Recommendations for Conducting Clinical Trials), within a country or professional community (codes, recommendations, etc.) [33-35]. The ethical principles of using the GET largely relate to germinal and embryonic human and animal cells, as well as human somatic cells modified for therapeutic purposes. The paramount ethical principle of working with GET is the well based rationale for the research where consideration is given to the balance of positive and negative consequences for a society, an individual, or an object undergoing the modification [36]. The necessity to apply additional ethical principles depends on the modified object. It is also worth noting that the existing ethical standards are not universal for all countries and largely determined by the sociocultural specifics, which, along with the difference in legal approaches to regulation, makes it difficult to achieve an international consensus on GET usage control.

Globally, the ethical and legal regulations of using the GET are complementary, while differing in the sources of norms formation and the ways to control safety.

\section{Legal regulation of animal} and plant genome editing for medical purposes

Using the GET for genetic modification of microorganisms, animals and plants can not only reduce the global shortage of food and clean fresh water, but also find a solution to many medical problems. For example, the technology makes it possible to increase the nutritional value of crops, to make them produce clinically significant antigens for the purpose of passive immunization, or to increase the availability and safety of animal organs transplanted to humans. In 2017, the results showing the feasibility of using the CRISPR/ Cas9 technology for that purpose were published [18]. The scientists inactivated endogenous retroviruses and turned off the genes of type I histocompatibility complex in the pig genome in order to reduce the rejection of transplanted animal organs by the immune system of the recipient organism and to reduce the incidence of tumors that might be caused by the endogenous retroviruses present in the pig genome [18]. Currently, the organs of these pigs are successfully undergoing preclinical studies in primates.

Another promising approach to using the GET in living organisms (not humans) for preventive medicine is the technology of gene drive, which is supposed to allow for controlling the spread of vector-borne diseases (malaria, dengue, Zika, etc.) $[4,18]$.

The very fact of genetic modification of animals and plants and the steady growth of so modified organisms [26] raises the issues of safety of GMO for humans, animals, and the environment and necessitates monitoring of the GMO distribution [4], as well as clarifying their legal status, especially due to their humanization. These factors call for creating a regulation framework for both the GET and the products resulted from their use. Many countries have already developed their official positions on these issues.

For example, the legal regulation in the US is aimed at 
specific biotechnological products [37]; the key document is named "Coordinated Framework for the Regulation of Biotechnology" [38]. The safety of organisms modified for medical purposes is controlled by the Food and Drug Administration (FDA) and Environmental Protection Agency (EPA). The EPA assesses the safety of a modified organism for the environment, and the FDA analyzes the safety of GMO as a nutritional material or a medication for humans and animals, taking into account possible long-term effects $[28,29]$. In the US, the production of genetically modified insects and their release into the environment is controlled by the Animal and Plant Health Inspection Service (APHIS) [26].

In Canada, Argentina, and India, there is no general regulation for GMO. The safety of each specific GMO for people and environment is evaluated per product, regardless of the method of its production [29, 37, 39].

The European Union has developed a legal framework based on Directive 2001/18/EC regulating the use of genetic engineering technology regardless of the characteristics of the final product [18, 40-42]. It is assumed that the delayed effects of GET are not well understood, therefore, all organisms exposed to them are subject to thorough examination and strict control [32]. Many countries, including Australia, New Zealand, and China, have not yet decided on the approach to regulating the GET and producing the GMO [37].

In the Russian Federation, according to Federal Laws No.149-FZ (dated December 17, 1997), No.7-FZ (dated January 10, 2002), and No.86-FZ (dated July 5, 1996, as amended on June 29, 2017), the prevailing approach is to control the technology, and not a specific product [43-45]; these laws prohibit the cultivation, breeding and release into the environment of organisms with the genome modified by genetic engineering and those containing foreign genetic material, except for the cultivation and breeding of such organisms for expert examination or scientific research. The import of GMO into Russia is not prohibited, but the Ministry of Health and Roszdravnadzor exercise control over GMO that are part of or have been used in the manufacture of medicines or medical products [45].

On the territory of the Eurasian Economic Union (EAEU), there is no special regulation of the GET, however, there are legal rules governing the registration, turnover, and use of GMO, regardless of the method of their production, but considering potential risks to the environment and humans [46].

A detailed list of legal norms and institutions regulating the use of GET for the purpose of modifying the genome of plants and animals, as well as the turnover and application of GMO in various countries, is given in the Table and Appendices 1 and 2.

Considering the ethical principles, it is rather problematic to breed animals with modified genomes that may cause suffering and premature death of these animals. On the other hand, such animal lines make it possible to model various incurable human diseases in order to find new approaches to their treatment, which to some extent justifies the conduct of such research.

\section{Bioethical and legal regulation \\ of human somatic cell genome editing}

The GET can be used to modify the genome of human somatic cells. Such modifications can be made both for research purposes (studying individual genes and proteins [47-49] or searching for the pathogenetic mechanisms [50-52]), as well as for the prevention and treatment of incurable diseases. The genome editing in human somatic cells for therapeutic purposes is possible both ex vivo and in vivo. At the current stage of GET development, ex vivo modification is preferable, since it is possible to monitor its efficiency and accuracy, as well as enrich the cell population before implantation [53]. Somatic cells with an ex vivo modified genome have been successfully used in clinical trials for the treatment of HIV infection and blood diseases [17, 18], epidermolysis bullosa [23] and oncological diseases $[22,54]$.

In vivo genome editing is practically the only option to modify the slowly renewing tissues (nervous, muscle, and myocardium), although this approach does not allow for evaluating the efficiency and accuracy of cell modification process, and also brings a potential threat of gamete modification [55]. The first clinical studies on the CRISPR/Cas9 system used for the correction of ex vivo and in vivo somatic cell genomes were reported to have begun in China [56]. Editas Biotechnologies (USA) plans to start a clinical study using this system in vivo to prevent the development of a hereditary disease (sexlinked Leber's amaurosis) [57]. Strategies for using GET in vivo to treat hemophilia $\mathrm{B}$, mucopolysaccharidosis I, cystic fibrosis, myodystrophy, and other hereditary disorders are under development [50].

One more type of the in vivo genome editing is aimed at preventing congenital fetus abnormalities by modifying fetal cells in utero. It has been shown [58] that prenatal intervention is more effective in preventing hereditary defects than editing the genome of a newborn child. At the same time, the risk of unintentional modification of fetal germ cells can be reduced by performing the procedure after 14-15 weeks of gestation, when the germ cells are already spatially isolated from the somatic cells $[59,60]$.

To reduce the likelihood of deliberate or unintentional harm to individuals and society as a whole, it is necessary to adapt the existing legislation or propose new laws that would effectively regulate this rapidly developing field of science. The basis for such legal framework can be taken from the directives and recommendations of the World Medical Association (WMA), the US Department of Health and Human Services (HHS), the Council of Europe and others [34, 61-63]. These documents regulate the rights of the patient as well as the general provisions and ethical 


\section{REVIEWS}

Legal institutions and legal standards regulating the use of genome editing technologies aimed at modifying the genome of plants, animals, somatic and germ cells in countries of the world

\begin{tabular}{|c|c|c|c|c|}
\hline Countries & $\begin{array}{l}\text { GMO safety } \\
\text { for the environment }\end{array}$ & GMO safety for humans & $\begin{array}{l}\text { Editing the genome } \\
\text { of human somatic cells }\end{array}$ & $\begin{array}{l}\text { Editing the genome of germ cells, } \\
\text { zygotes, and embryos } \\
\text { at early developmental stages }\end{array}$ \\
\hline Over the world & UN $(1,2)[97]$ & CAC (FAO/WHO) (3) [97] & $\begin{array}{l}\text { WMA, UNESCO, CIOMS, ISSCR } \\
(4-8)[98,99]\end{array}$ & $\begin{array}{l}\text { WMA, UNESCO, CIOMS, } \\
\text { ISSCR (4-8) [98-100] }\end{array}$ \\
\hline USA & $\begin{array}{c}\text { USDA, EPA, APHIS } \\
(9-12)[101]\end{array}$ & FDA (11-14) [102] & $\begin{array}{l}\text { HHS, NIH, HMD, RAC, FDA, IRB, } \\
\text { IBC }(13,15-18)[50,53,103]\end{array}$ & $\begin{array}{c}\mathrm{NIH}, \mathrm{FDA}, \mathrm{NBAC}, \mathrm{HMD}, \mathrm{CIRM} \\
(17,19,20)[50]\end{array}$ \\
\hline Canada & $\begin{array}{c}\text { CFIA, EnC, PMRA (21-25) } \\
{[104,105]}\end{array}$ & CFIA, HC (26-28) [105] & $\mathrm{HC}(27,29)[103,106,107]$ & $\begin{array}{l}\text { BANNED! HC, RCNRT } \\
\text { (30) }[100,106-108]\end{array}$ \\
\hline Brazil & CTNBio, NBC $(31)[39,109]$ & CTNBio, NBC $(31)[39,109]$ & $\begin{array}{l}\text { CTNBio, NBC, ANVISA, ACACT, } \\
\text { CONEP }(31-33)[103,109]\end{array}$ & $\begin{array}{c}\text { BANNED! } \\
\text { CTNBio, NBC, ANVISA, } \\
\text { ACACT, CONEP (31-33) [109] }\end{array}$ \\
\hline Argentine & SALFF, CONABIA (34-38) [20] & SALFF, SENASA (39) [20] & NMH, ANMAT $(37,40)[110,111]$ & $?$ \\
\hline EU & $\begin{array}{l}\text { ECm, National competent } \\
\text { authorities }(41-44)[39,109]\end{array}$ & $\begin{array}{c}\text { ECm, National competent } \\
\text { authorities, SCFA, EFSA } \\
(41,45)[39,109,111]\end{array}$ & $\begin{array}{c}\text { ECm, EMA, CAT, CHMP, NCA } \\
(46,47 \text {, etc. })[50,103,112,113]\end{array}$ & $\begin{array}{c}\text { BANNED! } \\
\text { EMA, UNESCO, CoE, CoB } \\
(48-53)[50,100,113]\end{array}$ \\
\hline UK & $\begin{array}{l}\text { FERA, DEFRA, ACRE } \\
(41-44,54,55)[39,114]\end{array}$ & $\begin{array}{c}\text { FERA, DEFRA, EFSA } \\
(41,45)[39,115]\end{array}$ & $\begin{array}{c}\text { GTAC, MHRA, HTA, BSGCT, } \\
\text { DEFRA, HSE, SACGM (EU laws, } \\
\text { U.K. Clinical Trials Regulations) } \\
{[112,113,116]}\end{array}$ & $\begin{array}{c}\operatorname{HFEA}(56,57) \\
{[50,100,114,117]}\end{array}$ \\
\hline France & $\begin{array}{l}\text { NASFE, HCB, CBMT } \\
(41-44,58-60)[39]\end{array}$ & $\begin{array}{c}\text { ANSES, HCB, MSH, MHERI } \\
(41,45,61)[39]\end{array}$ & $\begin{array}{l}\text { NMA, HCB, CPPs (EU laws, } \\
61,62)[103,112,113,118]\end{array}$ & $\begin{array}{c}\mathrm{AoB}(61,63-65) \\
{[100,107,113,119]}\end{array}$ \\
\hline Germany & $\begin{array}{l}\text { FOCPFS, CCBS } \\
(41-44,63)[39]\end{array}$ & $\begin{array}{c}\text { FOCPFS }(41,45,66,67) \\
{[39]}\end{array}$ & $\begin{array}{c}\text { PEI, FIDMD (EU laws, 68, 69) } \\
{[103,112,113,120]}\end{array}$ & $\begin{array}{l}\text { BANNED! CECSCR, GFMC, } \\
\text { GRCE }(70-74)[100,113,121]\end{array}$ \\
\hline Sweden & $\begin{array}{l}\text { SEPA, SAWM, SBoA, NBoF, } \\
\text { SGTAB }(41-44,75-77) \text { [39] }\end{array}$ & $\begin{array}{c}\text { NFA, SGTAB } \\
(41,45,78,79)[39]\end{array}$ & $\begin{array}{c}\text { MPA, SWEA, SGTAB, SEPA, } \\
\text { EthC (EU laws, 80-83) } \\
{[112,113,122,123]}\end{array}$ & $\begin{array}{c}\text { MHSA, NBHW, SNCB } \\
(48-53,84-86) \\
{[113,124,125]}\end{array}$ \\
\hline China & $\begin{array}{l}\text { MoA, MoF, GAQIQ, BRI, } \\
\text { GMOBC (87-93) [39] }\end{array}$ & $\mathrm{MoH}, \mathrm{MoA}(91)$ [39] & MoH, MoST, CFDA (94-99) [126] & $\begin{array}{c}\text { MoH, MoST, CFDA, NHFPC } \\
(94-96,98,100-104) \\
{[50,100,127]}\end{array}$ \\
\hline India & $\begin{array}{l}\text { MoEF, IMoA, DoB, RDAC, } \\
\text { RCGM, GEAC, NBPGR } \\
(105-108)[128]\end{array}$ & $\begin{array}{l}\text { MoHFW, MoFPI, CCFS, } \\
\text { NMAIF }(109,110)[128]\end{array}$ & $\begin{array}{c}\text { MoHFW, ICMR DoB, CDSO, } \\
\text { DoST (111) } \\
{[129,130]}\end{array}$ & $\begin{array}{c}\text { ICMR, DoB, NCSRT } \\
(111,112) \\
{[100,129]}\end{array}$ \\
\hline Japan & $\begin{array}{c}\text { MoE, MAFF, MEXT, METI } \\
(113-115) \text { [39] }\end{array}$ & MHLW, FSC (116-118) [39] & MHLW (119-122) [103] & $\begin{array}{c}\text { MHLW, MEXT }(123,124) \\
{[100,103]}\end{array}$ \\
\hline South Africa & $\begin{array}{l}\text { DAFF, ExC, Registrar, AdC, } \\
\text { SANBI, DEA }(125,126)[39]\end{array}$ & DoH $(125,127,128)[39]$ & $\begin{array}{c}\text { DoH, NHREC, HPCSA, MCC } \\
(125,129-136)[131]\end{array}$ & $\begin{array}{c}\text { DoH, NHREC } \\
(125,129,130,135,137)[131]\end{array}$ \\
\hline RF & $\begin{array}{c}\text { Rosselkhoznadzor, } \\
\text { Rosprirodnadzor } \\
\text { (No.149-FZ, 1997; No.7-FZ, } \\
\text { 2002; No.86-FZ, 1996) } \\
{[39,43-45,132]}\end{array}$ & $\begin{array}{c}\text { Rospotrebnadzor, } \\
\text { Rosselkhoznadzor, Ministry } \\
\text { of Health, Roszdravnadzor } \\
(\text { No.86-FZ, 1996) } \\
{[39,45,132]}\end{array}$ & $\begin{array}{c}\text { Ministry of Health, Roszdravnadzor } \\
\text { (No.180-FZ, 2016; 86-FZ, 1996; } \\
\text { 323-FZ, 2011; 61-FZ, 2010) } \\
{[45,75,77,78,132]}\end{array}$ & $\begin{array}{c}\text { Ministry of Health RF (No.180-FZ, } \\
\text { 2016; 86-FZ, 1996; 323-FZ, 2011; } \\
\text { 61-FZ, 2010; 54-FZ, 2002; } \\
\text { Order of Ministry of Health } \\
\text { No.107n dated August 30, 2012) } \\
\text { [45, 75, 77, 78, 91, 92, 132] }\end{array}$ \\
\hline
\end{tabular}

$\mathrm{N}$ o t e: for the full names of the regulatory organizations, see Appendix 1; numbers in parentheses denote normative acts regulating a specific application of the GET in this country/world — see Appendix 2; numbers in square brackets correspond to the list of references

aspects of clinical trials. The expected document should pertain specifically to the research into new GET (and the delivery options), which are aimed at correcting somatic pathologies; the major emphasis should be made on safety for the researchers and the environment, as well as on preventing any unintentional modification of the germ cell genome in vivo [50,64, 65].

The creation of international standards for clinical trials is supervised by the Council for International Organizations of Medical Sciences (CIOMS) [8]. 
An analysis of the existing regulations showed that the ethical and legal standards developed for gene therapy and cell products for medical use are mainly suitable for regulating the genome editing experimentation with human somatic cells for therapeutic purposes [66]. However, a high probability of accidental, inappropriate DNA modification (especially, with in vivo editing) requires the introduction of additional standards and control measures that do not exist at the moment [50]. At the same time, attempts to stop the progression or cure an incurable disease using any technology that carries a certain health risk, are, from our point of view, ethically justified and require a softer regulation as far as the GET for somatic cells is concerned.

In this situation, the European Medicines Agency (EMA) announced that an additional public hearing would be held in the near future to update the existing directives (current 2001/20/EC and 2001/83/EC, Supplement No.1394/2007 to the Regulation (EC) No.726/2004) on the issue of using cells with an edited genome [12].

In the UK, gene and cell products, as well as their clinical trials, are supervised by Gene Therapy Advisory Committee (GTAC) and the Department of Health \& Social Care UK; the latter includes the Health and Safety Executive Scientific Advisory Committee on Genetically Modified Organisms and the Medicines and Healthcare Products Regulatory Agency (MHRA), and the Human Tissue Authority (HTA). The arrangements for clinical trials are determined by the UK Clinical Trials Regulations [67]. The GTAC is involved in the assessment and approval of the ethical aspects of clinical research in the field of regenerative medicine; the HTA monitors the safety and ethical aspects of the circulation of human organs and tissues, and also licenses the participating organizations; the MHRA controls the production and distribution of innovative medical devices [50, 68, 69]. In the UK, popularization and public discussion on new medical technologies takes place within the Public Engagement Day, annually organized by the British Society for Gene and Cell Therapy (BSGCT), which is a branch of the Department of Health \& Social Care UK [70].

In the US, clinical trials of a new gene therapy or genome editing product are monitored by the $\mathrm{NIH}$ Recombinant DNA Advisory Committee (RAC), U.S. Food and Drug Administration and its divisions: Center for Biologics Evaluation and Research (CBER) and Office of Tissues and Advanced Therapies. At the level of scientific and medical institutions, additional control is exercised by the local Institutional review board (IRB) and the Institutional Biosafety Committee (IBC) [50]. The RAC initiates a comprehensive discussion of the research protocol in the community and among experts, makes recommendations for clinical trials and has the right to approve the procedure for the delivery of recombinant DNA and GET components. The IRB evaluates the research protocol, potential benefits and risks of its implementation and approves the conduct of a specific study in a specific institution, including studies in humans $[50,53]$. CBER regulates products and delivery vehicles for gene therapy; after completing the clinical trial, the FDA and CBER monitor the status of study participants in order to detect potential longterm side effects [71]. In addition, the Cellular, Tissue and Gene Therapies Advisory Committee, funded by the FDA, reviews and evaluates all available information about the safety, efficacy, and proper use of gene and cell therapy for a wide range of pathological conditions. This monitoring at several levels increases the likelihood of a comprehensive and unbiased examination before and during clinical trials [50].

The Food and Drug Administration, as the main regulator of genetically engineered products (from plasmids to ex vivo modified cells), published several issues of recommendations for researchers: Points to Consider and Considerations for the Design of EarlyPhase Clinical Trials of Cellular and Gene Therapy Products [72, 73].

In some cases, FDA protocols allow for an accelerated approval of test drugs, including those from the field of cell therapy and regenerative medicine, based on preliminary results of clinical trials and data obtained from external sources (for example, from studies on a similar drug), or if the drug has a unique potential for treating a serious or life-threatening disease [74].

In Singapore, Japan, and South Korea, the regulation concerning the clinical trials of gene therapy products is very similar to that in the United States: in these countries, there is also a mechanism of "conditional approval" for products of regenerative medicine [50].

Currently, the legislation in China does not yet fully regulate the use of GET for medical purposes; therefore, they follow the guidelines developed by the China Food and Drug Administration (CFDA) for gene and cell therapy, whereas clinical and preclinical studies in this area are regulated by analogy with the similar procedures existing in the US. In addition to the CFDA, the Health and Family Planning Commission (HFPC) also monitors the use of GET [50].

In Russia, a specific regulatory document on the medical use of GET has not yet been formalized, yet the existing laws do not explicitly regulate the use of these technologies. The most probable area of medical use of GET - ex vivo editing of the somatic cell genome falls under the regulation of Federal Law No.180-FZ "On Biomedical Cell Products" and its by-laws [75, 76].

The use of GET products for modifying the genome in vivo or in utero may fall within the scope of regulations listed in the Federal Laws No. 61-FZ and No. 86-FZ: "On Circulation of Medicines" [77] and "On State Regulation in the Field of Genetic Engineering", respectively [45]. It is worth noting that the use of GET for editing the genome of human somatic cells in vivo and ex vivo does not contradict the law No.323-FZ "On the basics 
of protecting the health of citizens in the Russian Federation" in its current version [78].

In the territory of the Customs Union, there is no special regulation of therapeutic drugs based on GET (as in the case of GMO). However, medicines obtained with the help of GET are subject to the legal act "Rules for conducting research on biological drugs in the territory of the Eurasian Economic Union", approved by the decision of the Council of the Eurasian Economic Commission No.89 dated November 3, 2016 [79]. This normative act includes the main provisions for controlling the circulation of gene therapy products, medications based on somatic cells and also tissue engineering products, while considering the risks for the environment and humans.

For a more detailed list of legal norms and institutions governing the use of GET in the field of genome editing in human somatic cells, see the Table.

\section{Legal regulation of genome editing \\ in germ cells, zygotes and embryos \\ in the early stages of development}

In addition to somatic cell genome editing, GET can also be used to modify the genome of germ cells, zygotes and embryos in order to consolidate the genetic traits of interest in the next generations. It is possible to create an inheritable mutation by modifying the somatic cell nucleus with its subsequent transfer to the ovum (somatic cell nucleus transfer) [28]. These technologies can be used for the prevention and treatment of monogenic or multifactorial diseases with a hereditary component [80]. Another potential and rather controversial area of GET is the introduction of inheritable modifications in the human genome in attempts to "improve" or adapt a human being to the conditions of a rapidly changing world. The irresponsible and hasty use of GET in this area is highly likely to create social inequality, discrimination, conflict and the revival of eugenics [81].

Despite the fact that so little is known about the genetics of the "improvements" [9, 50], this problem ceased to be only theoretical at the end of 2018. Thus, in the above-mentioned case of twin girls with a modified genome born in China, the editing was carried out not with the aim of correcting the existing genetic defect, but with the goal of "improving" the nature of a human being [5]. The lack of a legal framework and the poor understanding of the technical and ethical consequences of GET made these children involuntary hostages of a vain researcher. This scandalous case should stimulate the creation of national and international moratoria on such a "research" under the threat of criminal prosecution.

However, it is possible that with time, after defining the permissible limits, developing legal and ethical standards, and creating appropriate institutions, the society will return to the idea of modifying the human nature to overcome the problems of overpopulation, climate change, environmental degradation, and also to accommodate to new habitats (aquatic, space, etc.). In any case, people with a modified and unmodified genome should have equal rights and freedoms in accordance with the provisions of the Universal Declaration of Human Rights [82].

All of the above allows us to conclude that this area of GET application is currently one of the most controversial, since it raises many legal and ethical issues, some of which are due to the technical imperfection of GET, such as insufficient accuracy and efficiency [83, 84], mosaicism of the obtained embryos, etc. Together with the absence of long-term observations on the consequences of using the GET, it is not possible to affirm that modifications of the genome will not lead to the development of genetic anomalies and will not have adverse effects on the health of the subsequent generations [85]. Today, it is very difficult to predict how the twins with the edited genome will live their life. It is possible that until the legal status of people with a modified genome is determined, the state may limit their rights for reproduction.

In parallel to GET with an unclear legal status, today there is a wide range of effective reproductive technologies (IVF using donor gametes and embryos, prenatal diagnostic technologies), which in principle cast doubt on the validity of using the GET for introducing inheritable modifications into the human genome [86]. Nevertheless, in the future, after the development of relevant legal standards, GET may be used to modify the germ cells of humans: for example, if parents wish to remain biological parents and if at least one of them has hereditary diseases [87].

In the professional community, tolerance to the idea of making inheritable changes in the human genome is growing, but only with the aim of treating or preventing serious diseases. The proponents argue that correction of damaged embryo genes is comparable to life or health saving surgical intervention. It is emphasized though that the changes introduced into the human genome should not lead to a split in the society, discrimination, and deterioration of the human genetic characteristics [88]. In this regard, any attempts to "produce" babies with "improvements" are considered unacceptable.

The main ethical and legal acts governing the genome editing in germ cells or human embryo cells should clearly distinguish between the use of GET for research purposes, for clinical application (i.e., for correcting clinically significant genomic disorders), or for the purpose of unlawful modifications.

The threat of the thoughtless use of GET quite justifiably led to a total ban on genetic modification of embryos (as of 2014) in most countries with advanced genetic technologies (Europe, Canada, Australia, Brazil, India, China, Japan, and South Korea) [89]. However, over time, a number of countries (France, Canada, China, India, Japan) launched a public discussion on 
scientific and ethical issues related to the use of GET for introducing inheritable genomic modifications [8, 12, 57, 90]; other countries have made regulatory relief for the modification of germ cells and human embryos and their use up to 14 days for research purposes (UK, Sweden) (Figure 2) [50]. However, the introduction of any inheritable modifications into the genome with the aim of having a baby is still prohibited in all countries with developed regulation in the field of gene technologies $[50,66]$

A rather controversial legal situation exists in the United States. On the one hand, it is prohibited to use public funds for the research involving the destruction of human embryos; moreover, the FDA would not approve clinical trials of heritable genetic modifications [16, 66, 80]. On the other hand, a large number of research projects related to heritable genome editing that have a direct access to the clinic are approved by the FDA and receive private funding. According to a comment by the National Academy of Sciences and the National Institute of Health in the United States, the transfer of these technologies to the clinic "is possible, but only after much more research", "only for good reason and under strict supervision", and taking into account the balance of all risks and possible benefits [80, 87]. Apparently, in the future, editing the embryo genome for medical purposes will be under the FDA control, which will issue permits for the modification after a careful assessment of preclinical and clinical data.

Some countries (China, India, Japan, Ireland) have not yet developed laws governing the introduction of inherited changes in the genome, and are guided thorough this area only by the general principles (i.e., a set of rules suggested by major national scientific groups) [50].
The regulatory framework for editing human embryos in China is governed by the "Regulatory Guidelines for Embryo Research and in vitro Fertilization" issued by the China Ministry of Health and the Health and Family Planning Commission [50]. However, the low social status of a human embryo in China (not considered a full-fledged human), the involvement of private laboratories in the human editing for medical purposes, and the desire of China to solve economic, social and political problems have already led to the birth of twin babies with an "improved" genome, contrary to the existing international ethical and legal standards [5].

The threat of new abuses in the area of GET persists, and not only in China, but also in other countries with underdeveloped or poor legislation in the field of genetic technologies (for example, most of the African countries) [81].

In the Russian Federation, the introduction of inheritable modifications to the human genome, as well as editing the somatic cell genome, is not regulated, and there is no direct prohibition on genome modification in embryonic or germ cells of humans. Creation of embryos for the treatment of infertility is permitted [91], but human cloning is prohibited [92]. Apparently in the Russian Federation, introducing inheritable modifications into the human genome should be proceeded according to international recommendations and legal procedures (ISSCR, European Court of Human Rights) [93, 94]: i.e., edit the genome of germ cells or human embryos only in case of emergency and for research purposes only; maintain the viability of modified embryos for no more than 14 days.

World religions also did not stand aside from the public discussion on the problems of inherited genome editing $[28,81]$. It is worth noting that the range of the

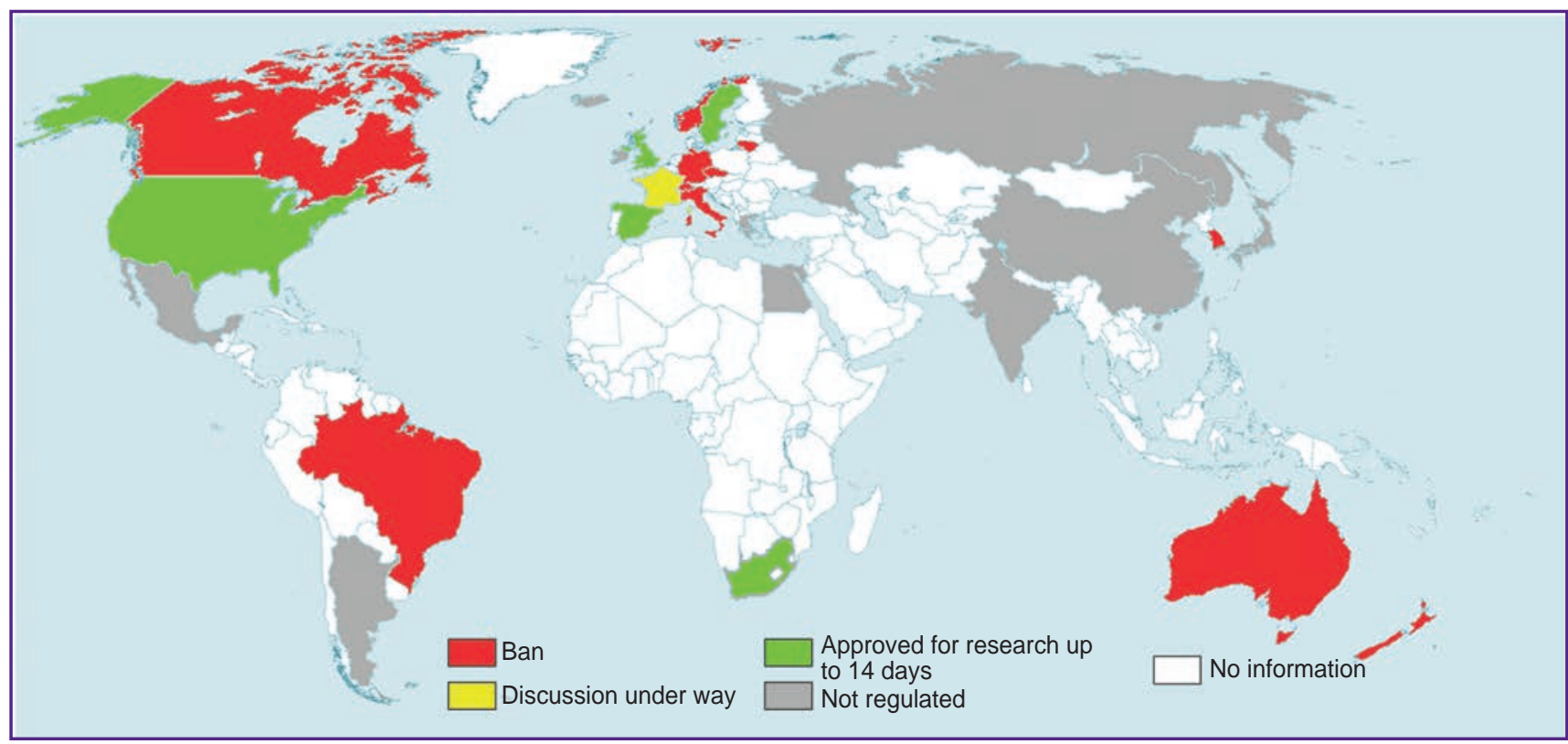

Figure 2. National policies regarding the genomic editing in zygotes, human embryonic stem cells and germ cells 
opinions is very wide: from the "unacceptability" to the need for "improving" the human nature; the theological views will inevitably influence the future of GET in different countries, cultures and regulatory systems. A detailed list of legal norms and institutions regulating the use of GET for inheritable genome modifications in countries with the most developed legislation concerning the gene technologies is presented in the Table.

In general, the world policy in the field of editing the embryo genome today is as follows: modification of the human embryonic line is unacceptable because no sufficient experience has been gathered on using the GET with human and animal tissues (including primates). However, to rule out any cases of repeated unlawful use of the GET, appropriate national and international legal acts should be put in place; those must explicitly regulate the use of GET for inheritable genome editing and provide for strict legal liability for its violation [9, 95].

\section{Conclusion}

The recently appeared GET will probably make it possible to realize the wildest dreams of the mankind about longevity and space exploration. However, the development of such powerful technologies is fraught with many dangers for the environment and human society. In this regard, the research and medical communities need flexible and effective regulations that would not impede the safe and effective genome editing but would block the unreasonable and risky experimentation with GET. A constructive position to minimize potential risks while maintaining the pace of technological development is (i) to remove the ban on the GET-associated research, (ii) maintain strict control over the use of modified plants and animals in agriculture, and (iii) introduce a temporary moratorium on the clinical use of GET. The accumulation of scientific and practical experience will make it possible to evaluate the long-term efficacy and safety of these technologies; the development of new tools and protocols for safety control will make it possible to gradually expand the scope of its use and remove the restrictions that have been introduced.

At the present stage, it is highly important to harmonize the ideas about the acceptable use of GET on the global scale and sign the international agreements on global biosafety including supranational regulation of these technologies. A reputable international organization (for example, UN or WHO) could initiate the development of such agreements. The first steps towards organizing the control over the global use of GET were made at the CRISPRcon 2017 conference [96] and other meetings on human genome editing $[10,11]$, where the issues of illegal use of GET (eugenics and bioterrorism) were raised. We believe that international cooperation and public discussion on the bioethical and legal aspects of GET with the adoption of relevant regulations may be the best alternative to the partial or complete prohibition of these promising technologies.

Research funding. The study was supported by the Russian Science Foundation (grant No.19-75-30007).

Conflict of interest. The authors have no conflict of interest.

Appendix 1

\section{ABBREVIATIONS OF THE REGULATORY ORGANIZATIONS}

ACACT - ANVISA Chamber for Advanced Cell Therapy; ACRE - Advisory Committee on the Release to the Environment; AdC - Advisory Committee; ANMAT - National Agency of Medicines, Food and Medical Technology; ANSES - Agency for Food, Environmental and Occupational Health \& Safety; ANVISA - National Agency for Health Surveillance; AoB - Agency of Biomedicine; APHIS - Animal and Plant Health Inspection Service; BRI - Biotechnology Research Institute; BSGCT — British Society for Gene and Cell Therapy; CAC - Codex Alimentarius Commission; CAT - Committee for Advanced Therapy; CBMT - Committee for Biological Monitoring of the Territory; CCBS - Central Committee for Biological Safety; CCFS - Central Committee for Food Standards; CDSO - Central Drugs Standard Organization; CECSCR - Central Ethics Commission on Stem Cell Research; CFDA - China Food and Drug Administration; CFIA - Canadian Food Inspection Agency; CHMP Committee for Human Medicinal Products; CIOMS - Council for International Organizations of Medical Sciences; CIRM California Institute for Regenerative Medicine; CoB - Committee on Bioethics; CoE - Council of Europe; CONABIA - National Advisory Committee on Agricultural Biotechnology; CONEP — National Research Ethics Committee; CPPs - Local Committee for Protection of People; CTNBio - National Technical Commission; DAFF - Department of Agriculture, Forestry and Fisheries; DEA — Department of Environmental Affairs; DEFRA — Department for Environment, Food and Rural Affairs; DoB — Department of Biotechnology; DoH - Department of Health; DoST - Department of Science and Technology; EFSA — Food Standards Agency, European Food and Safety Authority; EPA - Environmental Protection Agency; EthC - Ethics Committee; ExC Executive Council; FAO - Food and Agriculture Organization (WHO); FDA - Food and Drug Administration; FSC - Food Safety Commission; ECm - European Commission; EFSA - European Food and Safety Authority; EMA — European Medicines Agency; EnC - Environment Canada; FERA — The Food \& Environment Research Agency; FIDMD — Federal Institute for Drugs and Medical Devices; FOCPFS - Federal Office of Consumer Protection and Food Safety; GAQIQ - General Administration of Quality Supervision, Inspection and Quarantine; GEAC - Genetic Engineering Approval Committee; GMOBC - GMO Biosafety Committee; GTAC - Gene Therapy Advisory Committee; HC - Health Canada; HCB - High Council for Biotechnologies; HFEA - Human Fertilisation and Embryology Authority; HHS - Department of Health and Human Services; HMD - Health and 
Medicine Division; HPCSA - Health Professions Council of South Africa; HTA — Human Tissue Authority; IBC — Institutional Biosafety Committee; ICMR — Indian Council of Medical Research; IMoA - Ministry of Agriculture (India); IRB — Institutional Review Board; ISSCR — International Society for Stem Cell Research; MAFF — Ministry of Agriculture, Forestry and Fisheries; MCC - Medicines Control Council; METI - Ministry of Economy, Trade and Industry; MEXT - Ministry of Education, Culture, Sports, Science and Technology; MHLW - Ministry of Health, Labour and Welfare; MHERI - Ministry of Higher Education, Research and Innovation; MHRA - Medicines and Healthcare Products Regulatory Agency; MHSA — Ministry of Health and Social Affairs; MoA - Ministry of Agriculture; MoE - Ministry of the Environment; MoEF — Ministry of Environment and Forests; MoF - Ministry of Forestry; MoFPI - Ministry of Food Processing Industries; MoH - Ministry of Health; MoHFW - Ministry of Health and Family Welfare; MoST — Ministry of Science and Technology; MPA - Medical Products Agency; MSH — Ministry for Solidarity and Health; NASFE - National Agency on Sanitary, Food, Environmental, and Workplace Safety; NBAC - National Bioethics Advisory Commission; NBC - National Biosafety Council; NBHW - National Board of Health and Welfare; NBoF The National Board of Forestry; NBPGR - National Bureau of Plant Genetic Resources; NCA — National Competent Authorities; NCSRT - National Apex Committee for Stem Cell Research and Therapy; NFA - National Food Agency; NHFPC - National Health and Family Planning Commission; NHREC - National Human Research Ethics Council; NIH — National Institutes of Health; NMA - National Medicine Agency; NMAIF — National Monitoring Agency for Irradiation of Food; NMH - National Ministry of Health; PEI — Paul-Ehrlich-Institut; PMRA — Pest Management Regulatory Agency; RAC — Recombinant DNA Advisory Committee; RCGM — Review Committee on Genetic Manipulation; RCNRT — Royal Commission on New Reproductive Technologies; RDAC - Recombinant DNA Advisory Committee; SALFF - Secretary of Agriculture, Livestock, Fisheries and Food; SANBI - South African National Biodiversity Institute; SAWM - Swedish Agency for Marine and Water Management; SBoA - Swedish Board of Agriculture; SCAGM - Scientific Advisory Committee on Genetically Modified Organisms; SCFA Standing Committee on the Food Chain and Animal Health; SENASA - National Service of Agricultural and Food Health and Quality; SEPA - Swedish Environmental Protection Agency; SGTAB - Swedish Gene Technology Advisory Board; SNCB Swedish National Council of Bioethics; SWEA - Swedish Working Environment Authority; UN — United Nations; UNESCO United Nations Educational, Scientific and Cultural Organization; USDA - United States Department of Agriculture; WHO World Health Organization; WMA — World Medical Association.

Appendix 2

\section{NORMATIVE ACTS REGULATING THE USE OF GET}

1 - Cartagena Protocol on Biosafety; 2 - The Guidance Framework for Testing Genetically Modified Mosquitoes; 3 - Guideline for the Conduct of Food Safety Assessment of Foods Derived from Recombinant-DNA Plants/Animals/Microorganisms; 4 World Medical Association's Declaration of Helsinki; 5 - Universal Declaration on Bioethics and Human Rights; 6 - International Ethical Guidelines for Health-Related Research Involving Humans; 7 - Guidelines for Stem Cell Research and Clinical Translation; 8 - Updated Guidelines for Stem Cell Research and Clinical Translation; 9 - National Environmental Policy Act; 10 - Toxic Substances Control Act; 11 - Coordinated Framework for the Regulation of Biotechnology; 12 - Plant Protection Act; 13 - Federal Food, Drug, and Cosmetic Act; 14 - Coordinated Framework for the Regulation of Biotechnology; 15 Public Health Act; 16 - Belmont Report; 17 - Guidelines for Human Embryonic Stem Cell Research; 18 - NIH Guidelines for Research Involving Recombinant or Synthetic Nucleic Acid Molecules; 19 - Scientific and Medical Accountability Standards; 20 - Statement on NIH Funding of Research using Gene-Editing Technologies in Human Embryos; 21 - Health of Animals Act; 22 - Plant Protection Act; 23 - Seeds Act; 24 - Fertilizers Act; 25 - Pest Control Products Act; 26 - Food and Drugs Act; 27 - Food and Drugs Regulations; 28 - Guidelines for the Safety Assessment of Novel Foods; 29 - Canada Health Act; 30 - Assisted Human Reproduction Act; 31 - Law No.11, 105 of March 24, 2005; 32 - Decree \#5591; 33 - ANVISA Board Resolutions \#56/2010 \& \#9/2011; 34 — Law on Seeds and Phytogenetic Creations; 35 - Law on the Promotion of the Development and Production of Modern Biotechnology; 36 - General Law on the Environment; 37 - Regulation No.7075/2011; 38 - Regulation No.173/2015; 39 - Resolution No.412/2002; 40 - Regulations No.6677/10, 1480/11; 41 - Directive 2001/18/ EC; 42 - Directives 2009/41/EC, 90/220/EC; 43 - Regulations No.1946/2003; 44 - Court of Justice of the European Union Judgment in Case C-528/16; 45 - Regulations No.178/2002, 1829/2003, 1830/2003, 852/2004, 853/2004, 503/2013; 46 Directives No.2001/20/EC (replaced by Regulation EU No.536/2014), 2001/83/EC, 2002/98/EC, 2002/623/EC, 2003/63/EC, 2004/23/EC, 2009/120/EC, 1394/2007/EC; 47 - Regulation No.726/2004; 48 - The Oviedo Convention; 49 - The Convention for the Protection of Human Rights and Dignity of the Human Being; 50 - Embryo Act; 51 - Report of the IBC on Updating Its Reflection on the Human Genome and Human Rights; 52 - Directive 98/44/EC; 53 - Statement on Genome Editing Technologies; 54 - Environmental Protection Act 1990; 55 - Genetically Modified Organisms (Deliberate Release) Regulations 2002; 56 - Human Fertilisation and Embryology (HFE) Act 1990 (updated 2008); 57 - HFEA's Code of Practice; 58 - Law 2008-595; 59 - Environmental Code; 60 - Rural Code; 61 - Public Health Code; 62 - Decree No.2012-1236; 63 - Code Civil; 64 - Law No.94-654 (1994, 2004, 2011); 65 - Law 2011-814; 66 - Genetic Engineering Act (1993, 2004); 67 - Act on Pharmaceutical Drugs; 68 - German Medicinal Products Act; 69 - Third Notification on Clinical Trials of Medicinal Products for Human Use; 70 - Embryo Protection Law (1990 2001, 2011); 71 - Stem Cell Act; 72 - German Embryo Protection Act; 73 - Adoption Brokerage Law; 74 - Guideline of the German Federal Medical Chamber; 75 - Environmental Code 2018; 76 - Regulation SFS 2002:1086; 77 - Environmental Oversight Regulation; 78 - Foodstuffs Act; 79 - Foodstuffs Regulation; 80 - LVFS 1995:3; 81 - LVFS 1962:2; 82 - Ordinance (2002:1086); 83 - Ethical Review of Research Involving Humans (2003:460); 84 - The Act on Measures for Purposes of Research or Treatment using Fertilized Human Ova (1991:115); 85 - The Genetic Integrity Act (2006:351); 86 — Statement of Opinion on Embryonic Stem Cell Research (03/2002); 87 — 
PRC Agriculture Law; 88 - PRC Law on Seeds; 89 - PRC Law on Fisheries; 90 - PRC Law on the Environment; 91 Regulations on Administration of Agricultural Genetically Modified Organisms Safety; 92 - Measures for Examination and Approval of Processing Agricultural GMO; 93 - Administrative Measures for Safety Control over Genetic Engineering; 94 — Drug Administration Law; 95 - Regulations on Ethical Review of Biomedical Research Involving Human Subjects; 96 - Regulations on Clinical Use of Medical Technologies; 97 - Guidance for Human Gene Therapy Research and Its Products; 98 - Guidelines for Ethical Review of Drug Clinical Trials; 99 - Guiding Principles for Human Gene Therapy Clinical Trials; 100 - Guidelines on Human Assisted Reproductive Technologies; 101 - Guidelines on Human Embryonic Stem Cell Research; 102 - Regulations on Stem Cell Clinical Research (Trial); 103 - Ethical Guiding Principles on Human Embryonic Stem Cell Research; 104 Notification on Self-Evaluation and Self-Correction Work; 105 - Environment Protection Act; 106 — Seed Bill; 107 — Regulations and Guidelines for Recombinant DNA Research and Biocontainment; 108 - Guidelines for Research in Transgenic Crops; 109 - Prevention of Food Adulteration Act; 110 - Food Safety and Standards Bill; 111 - Ethical Guidelines for Biomedical Research on Human Participants; 112 - National Guidelines for Stem Cell Research; 113 — Basic Matters Ordinance No.1 of 2003; 114 - Ordinance to Designate Measures to Prevent Dispersal of GMOs During Their Industrial Use Among Type 2 Use; 115 - Ordinance to Designate Measures to Prevent Dispersal of GMOs During Their Type 2 Use for Research and Development Purposes; 116 - Pharmaceutical Affairs Act; 117 - Food Sanitation Law; 118 - Food Safety Basic Law; 119 - Act on the Safety of Regenerative Medicine; 120 - Pharmaceuticals and Medical Devices Act; 121 - Guidelines for Ensuring of Quality and Safety of GT Products; 122 - Guidelines for Gene Therapy Clinical Research; 123 — Ethical Guidelines for Human Genome and Gene Analysis; 124 - Guidelines for Derivation and Utilization of Human Embryonic Stem Cells; 125 Genetically Modified Organisms Act 1997; 126 - National Environmental Management Biodiversity Act; 127 - Consumer Protection Act; 128 - Foodstuffs, Cosmetics and Disinfectants Act; 129 - Bill of Rights; 130 - National Health Act; 131 Health Professions Act; 132 - Medicines and Related Substances Control Act; 133 - Medical Innovation Bill; 134 - Code of Ethics; 135 - Regulations Regarding the General Control of Human Bodies, Tissue, Blood, Blood Products and Gametes; 136 ICH Harmonised Tripartite Guidelines; 137 - Regulations Regarding Artificial Fertilisation and Related Matters.

\section{References}

1. Bhat S.A., Malik A.A., Ahmad S.M., Shah R.A., Ganai N.A., Shafi S.S., Shabir N. Advances in genome editing for improved animal breeding: a review. Vet World 2017; 10(11): 1361-1366, https://doi.org/10.14202/vetworld.2017. 1361-1366.

2. Donohoue P.D., Barrangou R., May A.P. Advances in industrial biotechnology using CRISPR-Cas systems. Trends Biotechnol 2018; 36(2): 134-146, https://doi.org/10.1016/j. tibtech.2017.07.007.

3. Wang C.X., Cannon P.M. Clinical applications of genome editing to HIV cure. AIDS Patient Care STDS 2016; 30(12): 539-544, https://doi.org/10.1089/apc.2016.0233.

4. Hammond A.M., Kyrou K., Bruttini M., North A., Galizi R., Karlsson X., Kranjc N., Carpi F.M., D'Aurizio R., Crisanti A., Nolan T. The creation and selection of mutations resistant to a gene drive over multiple generations in the malaria mosquito. PLoS Genet 2017; 13(10): e1007039, https://doi.org/10.1371/journal.pgen.1007039.

5. Cyranoski D. The CRISPR-baby scandal: what's next for human gene-editing. Nature 2019; 566(7745): 440-442, https://doi.org/10.1038/d41586-019-00673-1.

6. Zayner J. URL: https://www.indiegogo.com/projects/diycrispr-kits-learn-modern-science-by-doing.

7. Berg P., Singer M.F. The recombinant DNA controversy: twenty years later. Proc Natl Acad Sci U S A 1995; 92(20): 9011-9013, https://doi.org/10.1073/pnas.92.20.9011.

8. Charo R.A. The legal and regulatory context for human gene editing. Issues in Science and Technology 2016; 32(3): 39-44.

9. Baltimore D., Berg P., Botchan M., Carroll D., Charo R.A., Church G., Corn J.E., Daley G.Q., Doudna J.A., Fenner M., Greely H.T., Jinek M., Martin G.S., Penhoet E., Puck J., Sternberg S.H., Weissman J.S., Yamamoto K.R. A prudent path forward for genomic engineering and germline gene modification. Science 2015; 348(6230): 36-38, https:// doi.org/10.1126/science.aab1028.
10. The National Academies of Sciences, Engineering, Medicine. International Summit on Human Gene Editing: a global discussion. 2015. URL: https://www.nap.edu/read/ 21913/chapter/1.

11. The National Academies of Sciences, Engineering, Medicine. Statement by the organizing committee of the Second International Summit on Human Genome Editing. 2018. URL: http://www8.nationalacademies.org/onpinews/newsitem. aspx?RecordID=11282018b.

12. Allen \& Overy. Regulating CRISPR genome editing in humans: where do we go from here? 2017. URL: http:// www.allenovery.com/publications/en-gb/Pages/August-2017Regulating-CRISPR-genome-editing-in-humans-where-do-wego-from-here--.aspx.

13. Nesbit R. It's time for rational regulation. The Biologist 2017; 64(4): 10. URL: https://thebiologist.rsb.org.uk/biologistopinion/159-biologist/opinion/1789-it-s-time-for-rationalregulation.

14. Ishii T., Pera R.A.R., Greely H.T. Ethical and legal issues arising in research on inducing human germ cells from pluripotent stem cells. Cell Stem Cell 2013; 13(2): 145-148, https://doi.org/10.1016/j.stem.2013.07.005.

15. Bio-IT World Staff. How the world's governments have regulated human genome editing. 2016. URL: http://www. bio-itworld.com/2016/1/25/how-worlds-governments-haveregulated-human-genome-editing.html.

16. Wired. CRISPR gene-editing gets rules. Well, guidelines, really. 2015. URL: https://www.wired.com/2015/12/ crispr-gene-editors-get-the-beginning-of-some-rules/.

17. Blackwell T. End Canada's criminal ban on contentious CRISPR gene-editing research, major science group urges. 2017. URL: https://nationalpost.com/health/end-canadascriminal-ban-on-contentious-crispr-gene-editing-researchmajor-science-group-urges.

18. McNally K. The future of genome editing and how it will be regulated. 2017. URL: https://phys.org/news/2017-01future-genome.html.

19. European Medicines Agency. Accelerated assessment. 
2016. URL: https://www.ema.europa.eu/human-regulatory/ marketing-authorisation/accelerated-assessment.

20. Sipp D. Conditional approval: Japan lowers the bar for regenerative medicine products. Cell Stem Cell 2015; 16(4): 353-356, https://doi.org/10.1016/j.stem.2015.03.013.

21. Biffi A., Montini E., Lorioli L., Cesani M., Fumagalli F., Plati T., Baldoli C., Martino S., Calabria A., Canale S., Benedicenti F., Vallanti G., Biasco L., Leo S., Kabbara N., Zanetti G., Rizzo W.B., Mehta N.A., Cicalese M.P., Casiraghi M., Boelens J.J., Del Carro U., Dow D.J., Schmidt M., Assanelli A., Neduva V., Di Serio C., Stupka E., Gardner J., von Kalle C., Bordignon C., Ciceri F., Rovelli A., Roncarolo M.G., Aiuti A., Sessa M., Naldini L. Lentiviral hematopoietic stem cell gene therapy benefits metachromatic leukodystrophy. Science 2013; 341(6148): 1233158, https://doi.org/10.1126/science.1233158.

22. Davila M.L., Sadelain M. Biology and clinical application of CAR T cells for B cell malignancies. Int J Hematol 2016; 104(1): 6-17, https://doi.org/10.1007/s12185-016-2039-6.

23. Hirsch T., Rothoeft T., Teig N., Bauer J.W., Pellegrini G., De Rosa L., Scaglione D., Reichelt J., Klausegger A., Kneisz D., Romano O., Secone Seconetti A., Contin R., Enzo E., Jurman I., Carulli S., Jacobsen F., Luecke T., Lehnhardt M., Fischer M., Kueckelhaus M., Quaglino D., Morgante M., Bicciato S., Bondanza S., De Luca M. Regeneration of the entire human epidermis using transgenic stem cells. Nature 2017; 551(7680): 327-332, https://doi. org/10.1038/nature24487.

24. Waltz E. USDA approves next-generation GM potato. Nat Biotechnol 2015; 33(1): 12-13, https://doi.org/10.1038/ nbt0115-12.

25. Fagan J. Summary of the tryptophan toxicity incident. URL: http://www.nemsn.org/Articles/summary_tryptophan\%20 Fagan.htm.

26. FDA. Regulation of intentionally altered genomic DNA in animals. 2017. URL: https://www.fda.gov/downloads/ AnimalVeterinary/GuidanceComplianceEnforcement/ Guidanceforlndustry/ucm113903.pdf.

27. GMO FAQs. How are governments regulating CRISPR and new breeding technologies (NBTS)? URL: https://gmo. geneticliteracyproject.org/FAQ/how-are-governmentsregulating-crispr-and-new-breeding-technologies-nbts/.

28. Carroll D., Charo R.A. The societal opportunities and challenges of genome editing. Genome Biol 2015; 16(1): 242, https://doi.org/10.1186/s13059-015-0812-0.

29. Sprink T., Eriksson D., Schiemann J., Hartung F. Regulatory hurdles for genome editing: process- vs. productbased approaches in different regulatory contexts. Plant Cell Rep 2016; 35(7): 1493-1506, https://doi.org/10.1007/s00299016-1990-2.

30. Araki M., Ishii T. Towards social acceptance of plant breeding by genome editing. Trends Plant Sci 2015; 20(3): 145-149, https://doi.org/10.1016/j.tplants.2015.01.010.

31. Barton J., Crandon J., Kennedy D., Miller H. A model protocol to assess the risks of agricultural introductions: a risk-based approach to rationalizing field trial regulations. Nat Biotechnol 1997; 15(9): 845-848, https://doi.org/10.1038/ nbt0997-845.

32. Huang S., Weigel D., Beachy R.N., Li J. A proposed regulatory framework for genome-edited crops. Nat Genet 2016; 48(2): 109-111, https://doi.org/10.1038/ng.3484.

33. HG.org. 2019. URL: https://www.hg.org/ethics.html.

34. World Medical Association. Declaration of Helsinki. Ethical principles for medical research involving human subjects. JAMA 2013; 310(20): 2191-2194, https://doi. org/10.1001/jama.2013.281053.

35. World Medical Association. Medical ethics manual. 2015. URL: https://www.wma.net/wp-content/uploads/2016/11/ Ethics_manual_3rd_Nov2015_en.pdf.

36. Rossant J. Gene editing in human development: ethical concerns and practical applications. Development 2018; 145(16): dev150888, https://doi.org/10.1242/dev.150888.

37. Schuttelaar and Partners. The regulatory status of new breeding techniques in countries outside the European Union. 2015. URL: https://www.nbtplatform.org/backgrounddocuments/rep-regulatory-status-of-nbts-oustide-the-eujune-2015.pdf.

38. U.S. Environmental Protection Agency. Modernizing the regulatory system for biotechnology products: final version of the update to the coordinated framework for the regulation of biotechnology. 2017. URL: https://www.epa.gov/regulationbiotechnology-under-tsca-and-fifra/modernizing-regulatorysystem-biotechnology-products.

39. Library of Congress. Restrictions on genetically modified organisms. 2014. URL: https://www.loc.gov/law/help/ restrictions-on-gmos/index.php.

40. Jin S. The ethical implications of a new gene editing technique. 2015. URL: https://www.weforum.org/ agenda/2015/03/the-ethical-implications-of-a-new-geneediting-technique/.

41. Peschin S. How should we regulate genome editing? 2017. URL: https://www.weforum.org/agenda/2017/05/howshould-we-regulate-genome-editing/.

42. Court of Justice of European Union. Organisms obtained by mutagenesis are GMOs and are, in principle, subject to the obligations laid down by the GMO Directive. 2018. URL: https://curia.europa.eu/jcms/upload/docs/ application/pdf/2018-07/cp180111en.pdf.

43. Federal'nyy zakon RF ot 17.12.1997 No.149-FZ "O semenovodstve". Sobranie zakonodatel'stva RF 1997, No.51, st. 5715 [Federal Law of the Russian Federation dated December 17, 1997 No.149-FZ "On seed production". Legislative Acts of the Russian Federation 1997, No.51, Art. 5715].

44. Federal'nyy zakon RF ot 10.01.2002 No.7-FZ "Ob okhrane okruzhayushchey sredy". Sobranie zakonodatel'stva RF 2002, No.47, st. 4659 [Federal Law of the Russian Federation dated January 10, 2002 No.7-FZ "On environmental protection". Legislative Acts of the Russian Federation 2002, No.47, Art. 4659].

45. Federal'nyy zakon RF ot 05.07.1996 ( $v$ red. ot 29.06.2017) No.86-FZ "O gosudarstvennom regulirovanii $v$ oblasti genno-inzhenernoy deyatel'nosti". Sobranie zakonodatel'stva RF 1996, No.28, st. 3348 [Federal Law of the Russian Federation dated 5 July, 1996 (as amended on June $29,2017)$ No.86-FZ "On state regulation in the field of genetic engineering". Legislative Acts of the Russian Federation 1996, No.28, Art. 3348]

46. Customs Union Commission. TR TS 021/2011 "O bezopasnosti pishchevoy produktsii" [TR TS 021/2011 "About food safety"]. URL: http://www.tsouz.ru/db/techreglam/ Documents/TR\%20TS\%20PishevayaProd.pdf.

47. Kalinina N., Klink G., Glukhanyuk E., Lopatina T., Efimenko A., Akopyan Z., Tkachuk V. MiR-92a regulates angiogenic activity of adipose-derived mesenchymal stromal cells. Exp Cell Res 2015; 339(1): 61-66, https://doi. org/10.1016/j.yexcr.2015.10.007. 
48. Kalinina N., Kharlampieva D., Loguinova M., Butenko I., Pobeguts O., Efimenko A., Ageeva L., Sharonov G., Ischenko D., Alekseev D., Grigorieva O., Sysoeva V., Rubina K., Lazarev V., Govorun V. Characterization of secretomes provides evidence for adipose-derived mesenchymal stromal cells subtypes. Stem Cell Res Ther 2015; 6: 1-12, https://doi.org/10.1186/s13287-015-0209-8.

49. Eremichev R.Y., Makarevich O.A., Alexandrushkina N.A. Kulebyakin K.Y., Dyikanov D.T., Makarevich P.I. Menstrualblood serum displays an antifibrotic effect on human endometrial mesenchymal stromal cells. Cell Tissue Biol 2018 12(4): 281-288, https://doi.org/10.1134/s1990519x1804003x.

50. The National Academies of Sciences, Engineering, Medicine Report. Human genome editing: science, ethics and governance. National Academies Press; 2017, https://doi. org/10.17226/24623.

51. Rysenkova K.D., Semina E.V., Karagyaur M.N., Shmakova A.A., Dyikanov D.T., Vasiluev P.A., Rubtsov Y.P., Rubina K.A., Tkachuk V.A. CRISPR/Cas9 nickase mediated targeting of urokinase receptor gene inhibits neuroblastoma cell proliferation. Oncotarget 2018; 9(50): 29414-29430, https://doi.org/10.18632/oncotarget.25647.

52. Tyurin-Kuzmin P.A., Karagyaur M.N., Rubtsov Y.P. Dyikanov D.T., Vasiliev P.A., Vorotnikov A.V. CRISPR/Cas9mediated modification of the extreme $\mathrm{C}$-terminus impairs PDGF-stimulated activity of Duox2. Biol Chem 2018; 399(5): 437-446, https://doi.org/10.1515/hsz-2017-0229.

53. Califf R.M., Nalubola R. FDA's science-based approach to genome edited products. 2017. URL: https://blogs.fda.gov/ fdavoice/index.php/2017/01/fdas-science-based-approach-togenome-edited-products/.

54. O'Rourke D.M., Nasrallah M.P., Desai A., Melenhorst J.J., Mansfield K., Morrissette J.J.D., MartinezLage M., Brem S., Maloney E., Shen A., Isaacs R., Mohan S., Plesa G., Lacey S.F., Navenot J.M., Zheng Z., Levine B.L., Okada H., June C.H., Brogdon J.L., Maus M.V. A single dose of peripherally infused EGFRvIll-directed CAR T cells mediates antigen loss and induces adaptive resistance in patients with recurrent glioblastoma. Sci Trans/ Med 2017 9(399): eaaa0984, https://doi.org/10.1126/scitranslmed. aaa0984.

55. Ho B.X., Loh S.J.H., Chan W.K., Soh B.S. In vivo genome editing as a therapeutic approach. Int J Mol Sci 2018; 19(9): E2721, https://doi.org/10.3390/ijms19092721.

56. Cyranoski D. CRISPR gene-editing tested in a person for the first time. Nature 2016; 539(7630): 479, https://doi. org/10.1038/nature.2016.20988.

57. Reardon S. First CRISPR clinical trial gets green light from US panel. Nature (News) 2016, https://doi.org/10.1038/ nature.2016.20137.

58. Rossidis A.C., Stratigis J.D., Chadwick A.C., Hartman H.A., Ahn N.J., Li H., Singh K., Coons B.E., Li Li, Lv W., Zoltick P.W., Alapati D., Zacharias W., Jain R., Morrisey E.E., Musunuru K., Peranteau W.H. In utero CRISPR-mediated therapeutic editing of metabolic genes. Nat Med 2018; 24(10): 1513-1518, https://doi.org/10.1038/s41591-018-0184-6.

59. Hill M.A. Embryology ovary development. URL: https:// embryology.med.unsw.edu.au/embryology/index.php/Ovary_ Development\#Human_Ovary_Timeline.

60. Hill M.A. Embryology testis development. URL: https:// embryology.med.unsw.edu.au/embryology/index.php/Testis_ Development.

61. World Medical Association. WMA Declaration of
Geneva. 2018. URL: https://www.wma.net/policies-post/wmadeclaration-of-geneval.

62. Department of Health, Education, and Welfare; National Commission for the Protection of Human Subjects of Biomedical and Behavioral Research. The Belmont Report. Ethical principles and guidelines for the protection of human subjects of research. J Am Coll Dent 2014; 81(3): 4-13.

63. Raposo V.L., Osuna E. European convention of human rights and biomedicine. Legal and Forensic Medicine 2013; 1405-1423, https://doi.org/10.1007/978-3-642-32338-6_98.

64. Bosley K.S., Botchan M., Bredenoord A.L., Carroll D., Charo R.A., Charpentier E., Cohen R., Corn J., Doudna J., Feng G., Greely H.T., Isasi R., Ji W., Kim J.S., Knoppers B., Lanphier E., Li J., Lovell-Badge R., Martin G.S., Moreno J., Naldini L., Pera M., Perry A.C., Venter J.C., Zhang F., Zhou Q. CRISPR germline engineering - the community speaks. Nat Biotechnol 2015; 33(5): 478-486, https://doi.org/10.1038/ nbt.3227.

65. Specter M. The gene hackers. 2015. URL: https://www. newyorker.com/magazine/2015/11/16/the-gene-hackers.

66. Kaiser J. U.S. panel gives yellow light to human embryo editing. Science 2017, https://doi.org/10.1126/science.aal0750.

67. Bamford K.B., Wood S., Shaw R.J. Standards for gene therapy clinical trials based on pro-active risk assessment in a London NHS Teaching Hospital Trust. QJM 2005; 98(2): 7586, https://doi.org/10.1093/qjmed/hci013.

68. Human Tissue Authority. Regulation of regenerative medicine in the UK. URL: https://www.hta.gov.uk/sites/default/ files/Role_of_regulators_in_regenerative_medicine.pdf.

69. Pocklington D. Genome editing of human cells. 2015. URL: http://www.lawandreligionuk.com/2015/09/08/genomeediting-of-human-cells.

70. Department of Health \& Social Care UK. British Society for Gene and Cell Therapy (BSGCT). Public engagement day 2019. 2019. URL: https://www.bsgct.org/public-engagementday-2019/.

71. FDA. Gene therapy clinical trials - observing subjects for delayed adverse events. Guidance for industry. 2006. URL: https://www.fda.gov/downloads/BiologicsBloodVaccines/ GuidanceComplianceRegulatory/nformation/Guidances/ CellularandGeneTherapy/ucm078719.pdf.

72. FDA. Points to consider in human somatic cell therapy and gene therapy. Hum Gene Ther 1991; 2(3): 251-256, https://doi.org/10.1089/hum.1991.2.3-251.

73. FDA. Considerations for the design of early-phase clinical trials of cellular and gene therapy products. 2015. URL: https://www.fda.gov/downloads/BiologicsBloodVaccines/ GuidanceComplianceRegulatoryInformation/Guidances/ CellularandGeneTherapy/UCM564952.pdf.

74. FDA. Fast track, breakthrough therapy, accelerated approval, priority review. 2015. URL: https://www.fda.gov/ forpatients/approvals/fast/default.htm.

75. Federal'nyy zakon RF ot 23.06.2016 No.180-FZ "O biomeditsinskikh kletochnykh produktakh". Sobranie zakonodatel'stva RF 2016, No.26, st. 3849 [Federal Law of the Russian Federation dated June 23, 2016 No.180-FZ "On biomedical cell products". Legislative Acts of the Russian Federation 2016, No.26, Art. 3849].

76. Makarevich P., Akopyan Z., Tkachuk V. On new regulation of cell therapy and regenerative medicine in the Russian Federation. Cytotherapy 2017; 19(9): 1125-1126, https://doi.org/10.1016/j.jcyt.2017.05.011.

77. Federal'nyy zakon RF ot 12.04.2010 No.61- 
FZ "Ob obrashchenii lekarstvennykh sredstv". Sobranie zakonodatel'stva RF 2010, No.16, st. 1815 [Federal Law of the Russian Federation dated April 12, 2010 No.61-FZ "On circulation of medicines". Legislative Acts of the Russian Federation 2010, No.16, Art. 1815]

78. Federal'nyy zakon RF ot 21.11.2011 ( $v$ red. ot 05.12.2017) No.323-FZ “Ob osnovakh okhrany zdorov'ya grazhdan v Rossiyskoy Federatsii". Sobranie zakonodatel'stva RF 2011, No.48, st. 6724 [Federal Law of the Russian Federation dated November 21, 2011 (as amended on December 5, 2017) No.323-FZ "On the basics of protecting the health of citizens in the Russian Federation". Legislative Acts of the Russian Federation 2011, No.48, Art. 6724].

79. EAEU. Pravila provedeniya issledovaniy biologicheskikh lekarstvennykh sredstv na territorii Evraziyskogo ekonomicheskogo soyuza. Reshenie No.89 ot 03.11.2016 [Rules for conducting research on biopharmaceuticals in the territory of the Eurasian Economic Union. Resolution No.89 dated November 3, 2016]. URL: http://pharmacopoeia.ru/wpcontent/uploads/2016/11/8903111.pdf.

80. Rubin C. Editing the book of life. URL: 2017, https:// www.lawliberty.org/2017/08/07/editing-the-book-of-life/.

81. Andoh C.T. Genome editing technologies: ethical and regulation challenges for Africa. International Journal of Health Economics and Policy 2017; 2(2): 30-46.

82. HG.org. 2019. URL: https://www.hg.org/human-rights. $\mathrm{html}$.

83. Karagyaur M., Rubtsov Y., Vasiliev P., Tkachuk V. Practical recommendations for improving efficiency and accuracy of the CRISPR/Cas9 genome editing system. Biochemistry (Mosc) 2018; 83(6): 629-642, https://doi. org/10.1134/s0006297918060020.

84. Dyikanov D.T., Vasiluev P.A., Rysenkova K.D., Aleksandrushkina N.A., Tyurin-Kuzmin P.A., Kulebyakin K.Y., Rubtsov Y.P., Shmakova A.A., Evseeva M.N., Balatskiy A.V., Semina E.V., Rostovtseva A.I., Makarevich P.I., Karagyaur M.N. Optimization of CRISPR/Cas9 technology to knock-out genes of interest in aneuploid cell lines. Tissue Eng Part C Methods 2019; 25(3): 168-175, https://doi.org/10.1089/ ten.tec.2018.0365.

85. de Lecuona I., Casado M., Marfany G., Lopez Baroni M., Escarrabill M. Gene editing in humans: towards a global and inclusive debate for responsible research. Yale J Biol Med 2017; 90(4): 673-681.

86. Missmer S.A., Pearson K.R., Ryan L.M., Meeker J.D., Cramer D.W., Hauser R. Analysis of multiple-cycle data from couples undergoing in vitro fertilization: methodologic issues and statistical approaches. Epidemiology 2011; 22(4): 497504, https://doi.org/10.1097/ede.0b013e31821b5351.

87. Ormond K.E., Mortlock D.P., Scholes D.T., Bombard Y., Brody L.C., Faucett W.A., Garrison N.A., Hercher L., Isasi R., Middleton A., Musunuru K., Shriner D., Virani A., Young C.E. Human germline genome editing. Am J Hum Genet 2017; 101(2): 167-176, https://doi.org/10.1016/j.ajhg.2017.06.012.

88. Sample I. Genetically modified babies given go ahead by UK ethics body. 2018. URL: https://www.theguardian.com/ science/2018/jul/17/genetically-modified-babies-given-goahead-by-uk-ethics-body.

89. Araki M., Ishii T. International regulatory landscape and integration of corrective genome editing into in vitro fertilization. Reprod Biol Endocrinol 2014; 12(1): 108, https:// doi.org/10.1186/1477-7827-12-108.

90. Blakemore E. First human embryos "edited" in U.S. - get the facts. 2017. URL: https://news.nationalgeographic. com/2017/08/human-embryos-gene-editing-crispr-us-healthscience/?user.testname=none.

91. Prikaz Ministerstva zdravoohranenija RF ot 30 avgusta 2012 g. No.107n g. Moskva "O porjadke ispol'zovanija vspomogatel'nyh reproduktivnyh tehnologij, protivopokazanijah i ogranichenijah $k$ ih primeneniju" [Order of the Ministry of Health of the Russian Federation dated August 30, 2012 No.107n, Moscow "On the procedure for using assisted reproductive technologies, contraindications and restrictions of their use"]. URL: https:// www.rosminzdrav.ru/documents/8023-prikaz-o-poryadkeispolzovaniya-vspomogatelnyh-reproduktivnyh-tehnologiyprotivopokazaniyah-i-ogranicheniyah-k-ih-primeneniyu.

92. Federal'nyj zakon RF ot 20.05.2002 №54-FZ "O vremennom zaprete na klonirovanie cheloveka". Sobranie zakonodatel'stva RF 2002, No.21, st. 1917 [Federal Law of the Russian Federation dated May 20, 2002 No.54-FZ "On a temporary ban on human cloning". Legislative Acts of the Russian Federation 2002, No.21, Art. 1917].

93. International Society for Stem Cell Research (ISSCR). Guidelines for stem cell research and clinical translation. 2016. URL: http://www.isscr.org/docs/default-source/all-isscrguidelines/guidelines-2016/isscr-guidelines-for-stem-cellresearch-and-clinical-translation.pdf?sfvrsn $=4$.

94. Plomer A. EU ban on stem cell patents is a threat both to science and the rule of law. 2011. URL: https://www.theguardian. com/science/blog/2011/dec/12/eu-ban-stem-cell-patents.

95. International Society for Stem Cell Research (ISSCR). ISSCR comments on U.S. study to correct disease genes in human embryos. 2017. URL: http://www.isscr.org/professionalresources/news-publicationsss/isscr-news-articles/articlelisting/2017/08/02/isscr-comments-on-u.s.-study-to-correctdisease-genes-in-human-embryos.

96. CRISPRcon. 2017. URL: https://crisprcon.org/ crisprcon-2017/.

97. Cartagena protocol on biosafety to the convention on biological diversity. Montreal; 2000. URL: https://www.cbd.int/ doc/legal/cartagena-protocol-en.pdf.

98. World Medical Association. WMA Declaration of Helsinki - ethical principles for medical research involving human subjects. 2018. URL: https://www.wma.net/policiespost/wma-declaration-of-helsinki-ethical-principles-for-medicalresearch-involving-human-subjects/.

99. UNESCO. Universal Declaration on Bioethics and Human Rights. 2005. URL: http://unesdoc.unesco.org/ images/0014/001461/146180E.pdf.

100. Witherspoon Council on Ethics and the Integrity of Science. The stem cell debates: lessons for science and politics. 2012. URL: https://www.thenewatlantis.com/publications/thestem-cell-debates-lessons-for-science-and-politics.

101. US Environment Protection Agency. The National Environmental Policy Act. 1969. URL: https://www.epa.gov/ laws-regulations/summary-national-environmental-policy-act.

102. FDA. Federal Food, Drug, and Cosmetic Act. 2018. URL: https://www.fda.gov/regulatoryinformation/ lawsenforcedbyfda/federalfooddrugandcosmeticactfdcact/ default.htm

103. Galli M.G., Serabian M. Regulatory aspects of gene therapy and cell therapy products. Adv Exp Med Biol 2015, https://doi.org/10.1007/978-3-319-18618-4.

104. Justice Laws Website. Plant Protection Act. 2019. URL: https://laws-lois.justice.gc.ca/eng/acts/P-14.8/. 
105. Canadian Food Inspection Agency. Regulating agricultural biotechnology in Canada: an overview. 2016. URL: http://www.inspection.gc.ca/plants/plants-with-noveltraits/general-public/overview/eng/1338187581090/13381885 93891.

106. Knoppers B.M., Isasi R., Caulfield T., Kleiderman E., Bedford P., Illes J., Ogbogu U., Ravitsky V., Rudnicki M. Human gene editing: revisiting Canadian policy. NPJ Regen Med 2017; 2(1): 3, https://doi.org/10.1038/s41536-0170007-2.

107. Knoppers B.M., Nguyen M.T., Noohi F., Kleiderman E. Human genome editing: ethical and policy considerations. 2018. URL: http://www.genomequebec.com/ DATA/PUBLICATION/34_en v Human_Genome_Editing_-Policy_Brief.pdf.

108. Canadian Institutes of Health Research. Human germline gene editing: points to consider from a Canadian perspective. 2016. URL: http://www.cihr-irsc.gc.ca/e/50158.html.

109. Presidency of the Republic Civil Cabinet Sub-Office of Legal Affairs. Law No.11.105. 2005. URL: http://www.wipo. int/edocs/lexdocs/laws/en/br/br060en.pdf.

110. National Administration of Drugs, Foods and Medical Devices. Regulation 6677/10. Buenos Aires; 2010. URL: http:// www.anmat.gov.ar/Comunicados/Dispo_6677-10_en.pdf.

111. Ministry of Health. Secretary Office of Policies, Regulations and Institutes. Regulation 7075. Buenos Aires; 2011. URL: https://www.fdanews.com/ext/resources/files/ archives/r/Reg7075-11RegistrationProceduresBiologicalPharm aProducts.pdf.

112. European Medicines Agency. Guidelines relevant for advanced therapy medicinal products. URL: https://www. ema.europa.eu/en/human-regulatory/research-development/ advanced-therapies/guidelines-relevant-advanced-therapymedicinal-products.

113. Kipling J. The European landscape for human genome editing. A review of the current state of the regulations and ongoing debates in the EU. 2016. URL: https://acmedsci. ac.uk/file-download/41517-573f212e2b52a.pdf.

114. Parliament of the United Kingdom. Environmental Protection Act 1990. URL: https://www.legislation.gov.uk/ ukpga/1990/43/contents.

115. European Food Safety Authority. GMO applications: regulations and guidance. URL: https://www.efsa.europa.eu/ en/applications/gmo/regulationsandguidance.

116. Genetherapynet.com. Gene therapy legislation in the United Kingdom. URL: http://www.genetherapynet.com/ europe/united-kingdom.html.

117. Parliament of the United Kingdom. Human Fertilisation and Embryology Act 2008. URL: https://www. legislation.gov.uk/ukpga/2008/22/contents.

118. Genetherapynet.com. Gene therapy legislation in France. URL: http://www.genetherapynet.com/europe/france.html.

119. Mahalatchimy A., Rial-Sebbag E. Regulation of stem cell research in France. 2017. URL. https://www.eurostemcell. org/regulation-stem-cell-research-france.
120. Genetherapynet.com. Gene therapy legislation in Germany. URL: http://www.genetherapynet.com/europe/ germany.html.

121. Small S. Regulation of stem cell research in Germany. https://www.eurostemcell.org/regulation-stem-cellresearch-germany.

122. Genetherapynet.com. Gene therapy legislation in Sweden. URL: http://www.genetherapynet.com/europe/ sweden.html.

123. MPA. The Medical Product Agency's provisions and guidelines on clinical trials of medicinal products for human use. 2003. URL: https://lakemedelsverket.se/upload/eng-mpase/lvfse/LVFS2003_6.pdf.

124. Ministry of Health and Social Affairs. The Genetic Integrity Act (2006:351). 2006. URL: http://www.smer.se/news/ the-genetic-integrity-act-2006351/.

125. Small S., Hovatta O. Regulation of stem cell research in Sweden. URL: https://www.eurostemcell.org/regulationstem-cell-research-sweden.

126. Genetherapynet.com. Gene therapy legislation in China. URL: http://www.genetherapynet.com/asia/china.html.

127. Rosemann A., Sleeboom-Faulkner M. New regulation for clinical stem cell research in China: expected impact and challenges for implementation. Regen Med 2015; 11(1): 5-9, https://doi.org/10.2217/rme.15.80.

128. Ahuja V., Jotwani G. The regulation of genetically modified organisms in India. 2007. URL: http://bch.cbd.int/ database/record. shtml?documentid $=42185$.

129. Tiwari S.S., Raman S., Martin P. Regenerative medicine in India: trends and challenges in innovation and regulation. Regen Med 2017; 12(7): 875-885, https://doi. org/10.2217/rme-2017-0094.

130. Chodisetty S., Nelson E.J. Gene therapy in India: a focus. J Biosci 2014; 39(3): 537-541, https://doi.org/10.1007/ s12038-014-9431-2.

131. Laurens J.B. A comparative analysis of the regulatory framework of the therapeutic application of stem cell technologies [dissertation]. University of Pretoria; 2017. URL: https://repository.up.ac.za/bitstream/handle/2263/62543/ Laurens_Comparative_2017.pdf?sequence=1\&isAllowed=y.

132. Postanovlenie pravitel'stva RF ot 29.06.2017 No.770 "O vnesenii izmeneniy $v$ postanovlenie Pravitel'stva RF ot 23.09.2013 g. No.839 "O gosudarstvennoy registratsii gennoinzhenerno-modifitsirovannykh organizmov, prednaznachennykh dlya vypuska $v$ okruzhayushchuyu sredu, a takzhe produktsii, poluchennoy s primeneniem takikh organizmov ili soderzhashchey takie organizmy". 2017 [Directive of the Government of the Russian Federation dated June 29, 2017 No.770 "On amending the directive of the Government of the Russian Federation dated September 23, 2013 No.839 "On state registration of genetically modified organisms intended for release into the environment, as well as products obtained using such organisms or containing such organisms" 2017]. URL: http://static.government.ru/media/files/12ZF6o3Z9m4toLDUehVz zeGLj201gv68.pdf. 